Original Research Article

\title{
Evaluation of antidepressant activity of tramadol in comparison with imipramine in Swiss albino mice
}

\author{
Chiranjeevi Bonda*, Sudhir Pawar, Jaisen Lokhande
}

\begin{abstract}
Department of Pharmacology, Lokmanya Tilak Municipal Medical College and Hospital, Mumbai, Maharashtra, India

Received: 18 December 2016 Accepted: 13 January 2017

*Correspondence to:

Dr. Chiranjeevi Bonda,

Email:

dr.chiranjeevimd@gmail.com
\end{abstract}

Copyright: (C) the author(s), publisher and licensee Medip Academy. This is an openaccess article distributed under the terms of the Creative Commons Attribution NonCommercial License, which permits unrestricted noncommercial use, distribution, and reproduction in any medium, provided the original work is properly cited.

\begin{abstract}
Background: The aim of the study was to evaluate the antidepressant effect of opioid analgesic tramadol using forced swim test and tail suspension test models.

Methods: The antidepressant effect was assessed by recording the immobility time in Forced swim test (FST) and Tail suspension test (TST). The mice were randomly divided into five groups. Mice belonging to group I was given normal saline $(0.1 \mathrm{ml} / \mathrm{kg})$ which acted as control. Group II received imipramine $(15 \mathrm{mg} / \mathrm{kg})$ considered as the standard drug tramadol was given in graded dose $(10,20$ and $40 \mathrm{mg} / \mathrm{kg})$ to mice of groups III, IV, V respectively. All drugs were administered intraperitoneally for seven successive days; test was done on 7th day.

Results: Tramadol and Imipramine showed antidepressant activity when compared to control. There is dose dependent increase in antidepressant activity of tramadol. The antidepressant activity of imipramine was significantly $(\mathrm{P}<0.05)$ more than tramadol at dose 10 and $20 \mathrm{mg} / \mathrm{kg}$ but antidepressant activity with tramadol $40 \mathrm{mg} / \mathrm{kg}$ was comparable to imipramine treated mice.

Conclusions: The results of this study indicated the presence of antidepressant activity of tramadol at $40 \mathrm{mg} / \mathrm{kg}$.
\end{abstract}

Keywords: Antidepressant, Forced swim test, Imipramine, Tail suspension test, Tramadol

\section{INTRODUCTION}

Depression is a common mental disorder characterized by sadness, loss of interest or pleasure, feeling of guilt or low self worth, disturbed sleep or appetite, feeling of tiredness or poor concentration. Major depression, persistent depressive disorder, bipolar depression, seasonal affective disorder, psychotic depression, postpartum depression, premenstrual dysphoric depression, situational depression and atypical depression are the various types of depression. ${ }^{1,2}$

Around 6.3 to $15.7 \%$ of the world population is suffering from depression with the prevalence of being 7 to $12 \%$ and 20 to $25 \%$ in men and women respectively. ${ }^{1,2}$ Commercially available antidepressants increases levels of serotonin, norepinephrine and or dopamine via different mechanisms and they offers benefits in both the short-term and long term. However even with a large array of drugs some problem in the management of depression persist in terms of intolerability, delayed therapeutic effects, limited efficacy in milder depression and existence of treatment resistant depression and there is a continued search for the more effective drugs with fewer side effects.

Tramadol is an opioid analgesic which is developed synthetically for the moderate to severe pain treatment. It is centrally acting analgesia which acts through dual mechanism that is weak $\mu$ opioid receptor agonist and nor epinephrine and serotonin reuptake inhibition, ${ }^{3}$ this mechanism occupies a paramount significance in choosing tramadol in this experiment and comparing with imipramine where latter also acts by similar mechanism. Tramadol has been shown to cause reuptake inhibition of nor epinephrine in locus coeruleus of pons in the brain. ${ }^{4}$ 
Norepinephrine reuptake inhibitors, serotonin noradrenaline reuptake inhibitors and norepinephrine dopamine reuptake inhibitors are found to be efficacious by acting on the very same location. We hypothesize that tramadol, by virtue of its property of blocking monoaminergic reuptake may acts as an antidepressant. Moreover, it has been noted by previous authors that the structure of tramadol resemble venlaflaxine and comparable in number of its molecular and pharmacological properties. $^{5}$

Few of the previous studies evaluated tramadol which exhibited anti depressant activity in mice using different experimental model of depression. ${ }^{6}$ A study showed that tramadol reduced the number of failures to avoid aversion in learned helplessness model in rats. ${ }^{6}$ However there was no agreement on the doses at which the effects were evident. Hence this study was undertaken for evaluating the dose dependent antidepressant activity of tramadol in albino mice and for the confirmation of the antidepressant activity of tramadol using different experimental models for the evaluation of antidepressant activity.

\section{METHODS}

\section{Drugs}

Test drug tramadol and standard drug imipramine were sourced from Sigma Aldrich Industries Ltd., Mumbai, normal saline procured from pharmacy of Lokmanya Tilak Municipal Medical College and Hospital, Mumbai.

Imipramine hydrochloride as a standard drug in the dose of $15 \mathrm{mg} / \mathrm{kg}$, tramadol as a test drug in doses of $10 \mathrm{mg} / \mathrm{kg}$, $20 \mathrm{mg} / \mathrm{kg}$ and $40 \mathrm{mg} / \mathrm{kg}$ and normal saline as a control in the dose of $0.1 \mathrm{ml} / 10 \mathrm{~g}$ were administered by intraperitoneal route for 7 days. Study was conducted on $7^{\text {th }}$ day.

The doses were selected after extrapolation of doses used in humans who ranged from minimum effective dose $(10 \mathrm{mg} / \mathrm{kg})$ as analgesic to sub maximal tolerated dose $(40 \mathrm{mg} / \mathrm{kg})$.

\section{Animals}

Swiss albino mice of either sex weighing 20-30g were used for the study. The mice were inbred in the central animal house of the Haffkine institute for training, research and testing, Mumbai under suitable conditions of housing, temperature, ventilation and nutrition. After procurement till the beginning of study, an interval of 1 week was scheduled for acclimatization of animals. A total of 30 animals $(n=30)$ were used. They were randomly divided into 5 groups of 6 animals each and were housed as 6 animals per cage. Animals were housed at a controlled temperature of $24^{\circ} \pm 3^{\circ} \mathrm{C}$, with a 12 hour light: dark cycle. The animals had free access to standard pellet and water. The groups were as follows:
- Group I: $0.1 \mathrm{ml} / 10 \mathrm{~g}$ of Normal saline intra peritoneally.

- Group II: $15 \mathrm{mg} / \mathrm{kg}$ Imipramine intra peritoneally

- Group III: $10 \mathrm{mg} / \mathrm{kg}$ of Tramadol intra peritoneally.

- Group IV: $20 \mathrm{mg} / \mathrm{kg}$ of Tramadol intra peritoneally.

- Group V: $40 \mathrm{mg} / \mathrm{kg}$ of Tramadol intra peritoneally.

The same set of animals was used for the two models with washout period of 14 days in between the 2 models.

\section{Evaluation of antidepressant activity}

\section{Forced swimming test [FST]}

The forced Swimming model to test for antidepressant activity was developed by Porsolt et al. ${ }^{7}$ The animals were forced to swim in a plastic cylinder measuring $30 \mathrm{X}$ $20 \mathrm{~cm}$ containing water at room temperature to a depth of $20 \mathrm{~cm}$. After an initial 2 minute period of vigorous activity, the total duration of immobility was recorded during next 4 minutes of total 6 minutes test Changes in immobility duration were studied after administering drugs.

\section{Tail suspension test [TST]}

The method was described by Steru et al. ${ }^{8}$ Animals were suspended upside down on a metal rod at a height of 55 $\mathrm{cm}$ from the ground with the help of an adhesive tape placed approximately $1 \mathrm{~cm}$ from the tip of the tail. The immobility displayed by rodents when subscribed this kind of unavoidable and inescapable stress has been hypothesized to reflect behavioural despair which in turn may reflect depressive disorders in humans. The total duration of immobility was recorded during next 4 minutes of total 6 minutes test. Changes in immobility duration were studied after administering drugs.

\section{Statistical analysis}

Results are presented as mean \pm SD. One way ANOVA was used for multiple comparisons. Following that Tukey's post hoc test was done for comparison between the groups. For all the tests a ' $\mathrm{P}$ ' value of $<0.05$ was considered statistically significant. Statistical analysis done by using Graphpad prism.

\section{RESULTS}

The present study was undertaken to evaluate the antidepressant activity of tramadol in forced swimming test and tail suspension test. The results showed that the immobility time in tramadol groups were significantly $(p<0.05)$ lesser than the control group of normal saline which signifies the antidepressant activity of tramadol. The decrease in immobility time signifying antidepressant activity with tramadol was dosing dependent Figure 1. Each histogram represents mean duration of immobility in seconds $(n=6)$. 


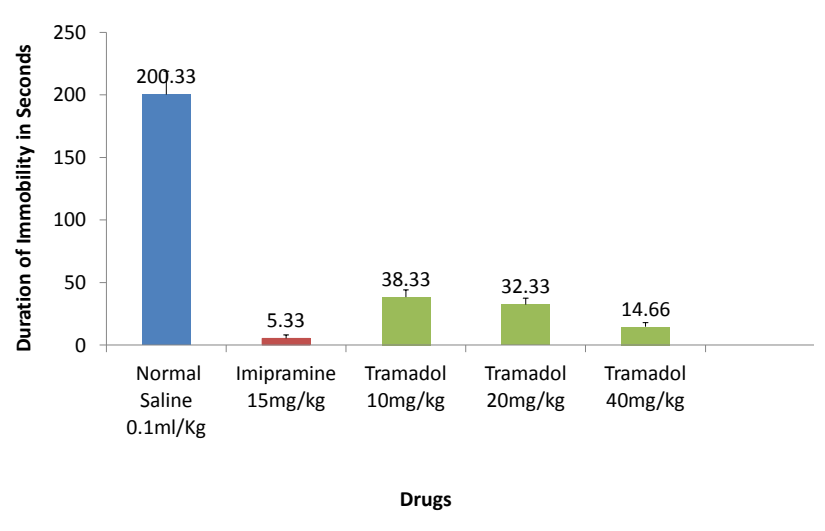

Figure 1: Observation of tramadol and imipramine on duration of immobility in forced swim test in swiss albino mice.

Vertical line represents SD. The standard antidepressant drug imipramine in the dose of $15 \mathrm{mg} / \mathrm{kg}$ significantly (p $<0.05)$ reduced the immobility time in comparison with the control group confirming its antidepressant activity. The mean immobility time with imipramine $15 \mathrm{mg} / \mathrm{kg}$ was also significantly greater than the tramadol $10 \mathrm{mg} / \mathrm{kg}$ and $20 \mathrm{mg} / \mathrm{kg}(\mathrm{p}<0.05)$. However the group on imipramine $15 \mathrm{mg} / \mathrm{kg}$ did not show significant difference compared to tramadol $40 \mathrm{mg} / \mathrm{kg}$, suggesting antidepressant activity of higher doses of tramadol to be comparable to the standard antidepressant drug imipramine.

Figure 1 shows that mean duration of immobility was reduced by imipramine and tramadol as compared to control in Forced Swim Test. The mean duration of immobility in control group (group I) was $200.33 \pm 7.62$ $\mathrm{sec}$, and in the standard imipramine group (group II) was $5.33 \pm 1.11 \mathrm{sec}$, in test groups tramadol $10 \mathrm{mg} / \mathrm{kg}$ (group III), $20 \mathrm{mg} / \mathrm{kg}$ (group IV) and $40 \mathrm{mg} / \mathrm{kg}$ (group V) groups, mean duration of immobility were $38.33 \pm 2.34$, $32.33 \pm 2.12$ and $14.66 \pm 1.33$ sec. respectively.

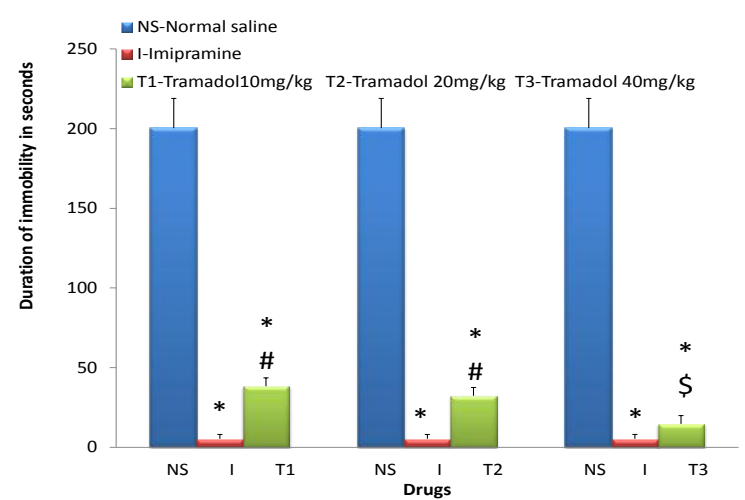

* $\mathrm{P}<0.05$ on comparison with Control group (Normal saline) \# P $<0.05$ on comparison of Tramadol $10 \mathrm{mg} / \mathrm{kg}$ and $20 \mathrm{mg} / \mathrm{kg}$ with Imipramine $15 \mathrm{mg} / \mathrm{kg}$

\$ P>0.05 on comparison of Tramadol $40 \mathrm{mg} / \mathrm{kg}$ with Imipramine $15 \mathrm{mg} / \mathrm{kg}$

Figure 2: Comparison of tramadol and imipramine on duration of immobility in forced swim test in swiss albino mice.
Figure 2 shows the comparison of efficacy (mean duration of immobility) of tramadol $(10,20,40 \mathrm{mg} / \mathrm{kg})$ versus imipramine and normal saline. Imipramine and all 3 doses of tramadol showed superior efficacy when compared with normal saline $(\mathrm{P}<0.05)$. Compared with imipramine, the antidepressant activity of tramadol 10 and $20 \mathrm{mg} / \mathrm{kg}$ were significantly lesser whereas tramadol $40 \mathrm{mg} / \mathrm{kg}$ showed comparable results with imipramine in terms of its antidepressant activity.

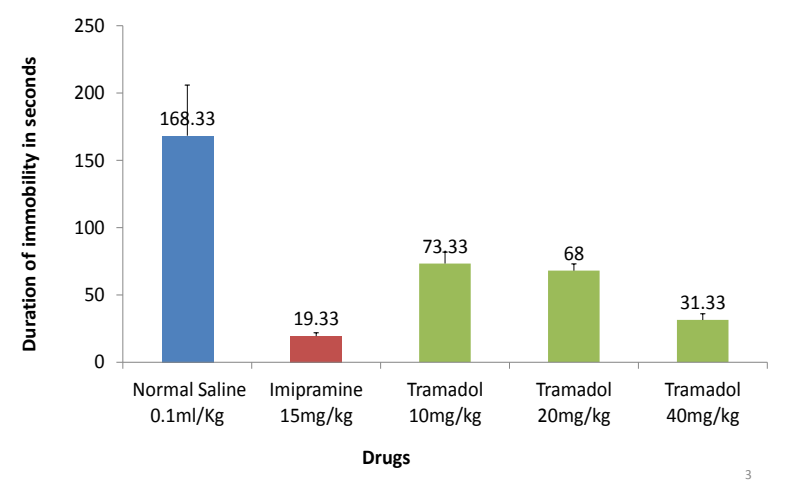

Figure 3: Observation of tramadol and imipramine on duration of immobility in tail Suspension Test in swiss albino mice.

Figure 3 shows that mean duration of immobility was reduced by imipramine and tramadol as compared to control group. The mean duration of immobility in control group (group I) was $168 \pm 15.38 \mathrm{sec}$ and in the standard imipramine group (group II) was 19.33 \pm 1.02 $\mathrm{sec}$, in test groups tramadol $10 \mathrm{mg} / \mathrm{kg}$ (group III), 20 $\mathrm{mg} / \mathrm{kg}$ (group IV) and $40 \mathrm{mg} / \mathrm{kg}$ (group V) groups, mean duration of immobility were $73.33 \pm 3.48,68 \pm 2.04$ and $31.33 \pm 1.89$ seconds respectively.

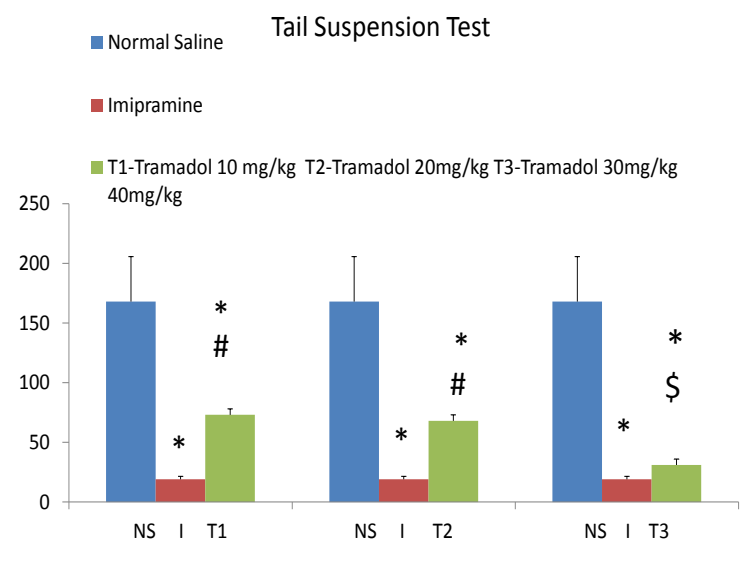

* $\mathrm{P}<0.05$ on comparison with Control group (Normal saline) \# $\mathrm{P}<0.05$ on comparison of tramadol $10 \mathrm{mg} / \mathrm{kg}$ and $20 \mathrm{mg} / \mathrm{kg}$ with Imipramine $15 \mathrm{mg} / \mathrm{kg}$

\$ P $>0.05$ on comparison of Tramadol $40 \mathrm{mg} / \mathrm{kg}$ with Imipramine $15 \mathrm{mg} / \mathrm{kg}$

Figure 4: Comparison of Tramadol and Imipramine on duration of immobility in tail suspension test in swiss albino mice. 
Figure 4 shows the efficacy (mean duration of immobility) of tramadol $(10,20,40 \mathrm{mg} / \mathrm{kg})$ in comparison with imipramine and normal saline. The figure also shows the comparison of tramadol (3 doses) with imipramine.

Imipramine and all 3 doses of tramadol showed superior efficacy when compared with normal saline $(\mathrm{P}<0.05)$. Compared with imipramine, the antidepressant activity of tramadol 10 and $20 \mathrm{mg} / \mathrm{kg}$ was significantly lesser as compared with the standard dose of imipramine whereas tramadol $40 \mathrm{mg} / \mathrm{kg}$ showed comparable results with imipramine in terms of its antidepressant activity in this model also.

\section{DISCUSSION}

Depression affects 350 million people and is among the leading causes of disability worldwide; constituting a major portion of mental health disorders. ${ }^{9}$

Depression is closely associated with brain monoaminergic system. Monoamines are neurotransmitters and neuromodulators that include serotonin, dopamine, norepinephrine and epinephrine. The monoamine hypothesis of depression postulates that the deficiency of certain neurotransmitters is responsible for the corresponding features of depression. Norepinephrine may be related to alertness and energy as well as anxiety, attention and interest in life. Many antidepressant drugs increase synaptic levels of the monoamine neurotransmitters.

Depression is a comorbid disabling syndrome that affects approximately $15 \%$ to $25 \%$ of cancer patients. Depression in patients with cancer not only affects the patients themselves but also has a major negative impact on their families. Depression is also prevalent among people with chronic pain which can be either due to cancer or other neuropathic pain conditions. ${ }^{10}$ Possible mechanisms for this relationship span the biopsychosocial spectrum and include shared neurophysiological, cognitive, environmental and predispositional factors. ${ }^{11}$

In antidepressant treatment, opioid peptide and their receptors are potential candidates. Tramadol has low affinity for opioid receptors. It acts centrally to produce the analgesic effects. Similar to antidepressant drugs tramadol has action on monoaminergic reuptake. ${ }^{12}$

The present study evaluated the possible antidepressant activity of the drug tramadol by using tail suspension and forced swimming test which is considered as gold standard model. In our study, we compared the antidepressant effect of tramadol with the standard antidepressant imipramine and Normal saline as control, using FST and TST models.
Mean difference of time for force swim test and tail suspension test were evaluated and difference were compared for significance of antidepressant activity. We found that tramadol has significant $(\mathrm{p}<0.05)$ antidepressant activity at all doses (10mg, 20mg and $40 \mathrm{mg}$ ) in comparison with control. Our finding is in concordance with established fact revealed by similar study in past. ${ }^{13}$

When tramadol was compared with imipramine for its antidepressant action, tramadol at dosage of $10 \mathrm{mg} / \mathrm{kg}$ and $20 \mathrm{mg} / \mathrm{kg}$ of tramadol did not show significant antidepressant effect compared to imipramine $(15 \mathrm{mg} / \mathrm{kg})$. However at higher dosage of $40 \mathrm{mg} / \mathrm{kg}$, significant antidepressant activity was seen compared to imipramine. Our finding was concurred by studies of Rojas et al, Kumar A et al and Karla B et al. ${ }^{14-16}$ which evaluated Tramadol using FST model. Tramadol at higher dose inhibits more number of transporters which results in increased reuptake inhibition.

Jesse et al demonstrated that with acute administration of tramadol in mice the anti depressant action was due to inhibition of $\mathrm{L}$ arginine nitric oxide guanylate pathway. ${ }^{17}$ They also proposed $\mathrm{K}^{+}$channels blockers in producing anti depressant effect in mice on oral administration of tramadol. ${ }^{18}$ Thus, it is concluded that tramadol has significant antidepressant activity.

Tramadol can also be evaluated for its antidepressant activity in comparison with newer antidepressants such as selective serotonin reuptake inhibitors.

The above results encourages us to do further evaluation of the tramadol in patients with severe pain and also having depression as a component including cancer patient and patients with chronic neurological pains like diabetes neuropathy, fibromyalgia etc.

\section{CONCLUSION}

From the study we can conclude that the tramadol has antidepressant activity which is comparable with the standard antidepressant agent. However, further studies would be necessary to evaluate the contribution of tramadol as antidepressant agent as monotherapy or in combination of other drugs, especially in patients with chronic severe pain.

\section{Funding: No funding sources \\ Conflict of interest: None declared}

Ethical approval: The study was approved by the Institutional Animal Ethics committee

\section{REFERENCES}

1. Diagnostic and Statistical Manual of Mental Disorders. $5^{\text {th }}$ ed, Text Revision ed. Washington, DC American Psychiatric Association; 2013. 
2. Rihmer Z, Angst J. Mood disorders: epidemiology, in Kaplan and Sadock's Comprehensive Textbook of Psychiatric, Sadock BJ and Sadocl VA; 2009.

3. DeBattista C, Antidepressant Agents: In Basic and Clinical Pharmacology, Bertram G. katzung, $11^{\text {th }}$ ed, Tata McGraw Hill New Delhi; 2009:509-531.

4. Sevcik J, Nieber K, Driessen B, Illes P. Effects of the central analgesic tramadol and its main metabolite, O-desmethyltramadol, on rat locus coeruleus neurones. Br J Pharmacol. 1993;110:169-76.

5. Kiayias JA, Vlacchou ED, Lakka PE. Venlafaxine $\mathrm{HCl}$ in the treatment of painful peripheral diabetic neuropathy. Diabetes Care. 2000;23:699.

6. Rojas-Corrales MO, Berrocoso E, Gibert-Rahola J, Mico JA. Antidepressant-like effects of tramadol and other central analgesics with activity on monoamines reuptake, in helpless rats. Life Sci. 2002;72:143-52.

7. Porsolt RD, Bertin A, Jalfre M. Behavioral despair in mice: a primary screening test for antidepressants. Arch Int Pharmacodyn Ther. 1977;229(2):327-36.

8. Steru L, Chermat R, Thierry B, Simon P. The tail suspension test: a new method for screening antidepressants in mice. Psychopharmacology (Berl). 1985;85(3):367-70.

9. World Health Organization. Depression. A Global Crisis. World Mental Health Day, Occoquan: World Federation for Mental Health; 2012:7.

10. Gagliese L, Gauthier LR, Rodin G. Cancer pain and depression: A systematic review of age-related patterns. PaiRes Manage. 2007;12(3):205-11.

11. Craig K. Emotions and psychobiology. In: Wall P, Melzack R, eds. Textbook of Pain. Edinburgh: Churchill Livingstone; 1999:331-344.

12. Baldessarini RJ. Drug therapy of depression and anxiety disorders.In: BruntonLL, Lazo JS, Parker
KL, editors. Goodman and Gilman's. The Pharrnacological Basis of Therapeutics. New York: McGraw Hill; 2006;431.

13. Lourdu A, Banupriya A, Meher Ali R. Antidepressant Effect of Tramadol on balb-c mice in Animal Models of Depression. Research Journal of Pharmaceutical, Biological and Chemical Sciences. 2013;4(2):1435-41.

14. Rojas-Corrales MO, Gibert-Rahola J, Mico JA. Tramadol induces antidepressant-type effects in mice. Life Sci. 1998;63:175-80.

15. Kalra BS, Tayal V, Chawala S. Antidepressant-like activity of tramadol in mice. Indian $\mathrm{J}$ Psychiatry. 2008;50(1):51-3.

16. Kumar A, Jayshree D, Rajshekar ST. Comparative efficacy of behavior despair models in depicting antidepressant like effect of tramadol. Int J Basic Clin Pharmacol. 2013;2(6):763-7.

17. Jesse CR, Bortolatto CF, Savegnago L, Rocha JBT, Nogueira CW. Involvement of L-arginine-nitric oxide-cyclic guanosine monophosphate pathway in the antidepressant-like effect of tramadol in the rat forced swimming test. Progress in neuropsychopharmacology and biological psychiatry. 2008;32(8):1838-43.

18. Jesse CR, Wilhelm EA, Barbosa NBV, Nogueira $\mathrm{CW}$. Involvement of different types of potassium channels in the antidepressant like effect of tramadol in the mouse forced swimming test. European journal of pharmacology. 2009;613(1-3):74-8.

Cite this article as: Bonda $\mathrm{C}$, Pawar S, Lokhande $\mathrm{J}$. Evaluation of antidepressant activity of tramadol in comparison with imipramine in Swiss albino mice. Int J Basic Clin Pharmacol 2017;6:695-9. 